\title{
A Critical Survey of Xhosa Lexicography 1772-1989
}

P.T. Mtuze, African Languages Department, Rhodes University, Grahamstown

Abstract: The artide critically surveys the development of dictionary making among the Xhosa. Besides being an analytical commentary on the earlier Xhosa dictionaries, it is also an overdue objective evaluation of The Greater Dictionary of Xhosa currently being compiled at the University of Fort Hare and which promises to be the most definitive Xhosa dictionary this century.

Keywords: DICTIONARIES, LEXICOGRAPHY IN AFRICA, HISTORICAL, CONTEMPORARY, SCENARIO, NEEDS, THE GREATER DICTIONARY OF XHOSA, POLICY, METHODOLOGY, CRITERIA, EVALUATION, PROBLEMS, TRANSLATABILITY.

Opsomming: 'n Kritiese oorsig van Xhosa-leksikografie 1772-1989. Hierdie artikel is 'n kritiese ondersoek na die ontwikkeling van die maak van woordeboeke onder die Xhosa. Benewens die feit dat dit 'n analitiese kommentaar is op die vroeëre Xhosa-woordeboeke, is dit ook 'n uitblywende objektiewe evaluasie van The Greater Dictionary of Xhosa, wat tans saamgestel word aan die Universiteit van Fort Hare. Dit belowe om die mees definitiewe Xhosa-woordeboek van hierdie eeu te wees.

Sleutelwoorde: WOORDEBOEKE, LEKSIKOGRAFIE IN AFRIKA, HISTORIES, KONTEMPORêR, SCENARIO, BEHOEFTES, THE GREATER DICTIONARY OF XHOSA, BELEID, METODOLOGIE, KRITERIA, EVALUERING, PROBLEME, VERTAALBAARHEID.

\section{Introduction}

Xhosa lexicographical studies cannot make much sense until we realise how it was possible for foreign scholars to get involved in this demanding and highly academic linguistic exercise given the fact that they were all non mother-tongue speakers of the language.

The reduction of Xhosa to writing started when the Rev. John Bennie arrived in 1821. He was a Scottish missionary who was sent to work among the amaNgqika (Xhosa) in what is now known as the Victoria East district. Like many other White missionaries, he was forced to learn the Xhosa language so that he could communicate with his potential converts. He got so interested in the language that he soon devised a basic alphabet and orthography.

Bennie was joined by another Scottish missionary in 1823 . This was the Rev. John Ross who had brought with him a small printing press by which the 
first ever Xhosa charts were produced. This is why Bennie is generally regarded as the father of Xhosa literature (Mahlasela 1973: 3). This was the beginning of the crossing of the language barriers in the Southern tip of Africa. The White missionaries started learning the Xhosa language while the Xhosas started learning English among other basic subjects.

Bennie and Ross's pioneering work unleashed a lot of activity in book production. The first book ever to be written in Xhosa, was Incwadi yokuqala ekuteteni ngokwamaXosa eTyume Ilizwe lamaXosa, yabadekwa lubadeko lwabaTunywa eGlasco 1824 (The first book in the language of the amaXhosa at Tyume, the land of the amaXhosa, and printed in the press of the missionaries from Glasgow in 1824) (Mahlasela 1973: 4).

There are several peculiarities in this book's title. Firstly, although it makes complete sense, it was written in the old orthography where aspiration was not reflected, hence ekuteteni instead of ekuthetheni, amaXosa instead of amaXhosa, eTyume instead of eTyhume, lwabaTunywa instead of lwabaThunyrva. The words yabadekwa and lubadeko are completely unintelligible today. It is of interest to note that the missionaries were aware, as early as that, of the fact that Xhosa has no diphthongs. They wrote eGlasco instead of eGlasgow

Another milestone that could be mentioned in passing was the appearance of the first grammar manuals, starting from A Systematic Vocabulary of the Kaffrarian Language in Two Parts to which is prefixed an Introduction to Kaffrarian Grammar in 1826 (Mahlasela 1973: 24). This was followed by several liturgical works and parts of the Bible. The complete Bible translation, however, appeared in 1887, two years after Soga's translation of Bunyan's The Pilgrim's Progress.

These developments were very important for the subsequent appearance of Xhosa dictionaries. The grammatical ground work had to be established before any attempts at recording and describing the language and its sound system could be made.

\section{The earlier history of Xhosa lexicography}

Dictionaries play an important role in all speech communities. A dictionary serves as an important reference work and greatly enhances the standardisation of a language as it tends to influence our use of language. Most people see the dictionary as a standard yardstick by which they should judge their own ability to spell and assign correct meanings to words. Pinchuk (1977: 223) says on the normative effect of a dictionary on language usage:

The dictionary is the reference book that is most generally associated with translating. It might even stand as a symbol for it, but it is an instrument to be used with caution and discernment. Many people regard dictionaries as infallible authorities on language usage, but this is not the view of 
lexicographers. For the lexicographer, the dictionary records and describes usage; it does not establish it. Yet this is not entirely true. There are labels in the standard monolingual dictionaries like 'slang' 'colloquial' and so on, and even in Webster's Seventh New Collegiate Dictionary (1967) we find the expression 'substandard'. These expressions are not only descriptive: they also carry social connotations. Certainly they will be viewed by the general public as deprecatory, regardless of the dictionary maker's intention.

This view of the force or influence of the dictionary is also confirmed by Leech (1974: 203):

We have learnt to go to 'the dictionary' for all manner of information on words (for example, their history or origin) apart from their form and behaviour in the present-day language: and even for information that may more properly belong to an encyclopedia (such as how to recognize the national flags of the world) or to a book of etiquette (such as how to address an archbishop). Further, the dictionary comes to be looked on as a legislative organ, to which one turns for a standard of 'good' as opposed to 'bad' usage. This attitude is indeed encouraged by the phrase 'the dictionary', with its misleading similarity to 'the Bible'.

The Xhosa lexicographical history is very interesting. It all started with Sparrman's (1785) list of Xhosa words and Barrow's list of Xhosa and Hottentot (sic) words in 1797-8, followed by Van der Kemp (1803) and Lichtenstein's (1805?) efforts and John Ayliff's $A$ Vocabulary of the Kafir Language, in 1846. In 1850 Appleyard published the Kaffir and English Dictionary. This was followed by $A$ Dictionary of the Kafir Language by W.J. Davis in 1872 and by Davis' English-Kafir Dictionary in 1877.

Another small but useful dictionary in its own time was James McLaren's A Concise Kafir-English Dictionary, published in 1915. This was followed by his other dictionary, A Concise English-Kafir Dictionary, in 1923. For many years, these were the only reliable or accessible dictionaries in Xhosa. The only disadvantage with both was that they contained numerous words that have now become obsolete and both contained very limited present day vocabulary, for example, words such as ifiva (fever), isipili (mirror), ipapa (porridge), ukupakanyela (to tackle as a group), ukupekisela (to scrutinize), to mention but a few.

It should be pointed out that the term Kafir was generally used with reference to the indigenous peoples of Africa. It is now legally offensive. Its place was later taken by many other derogatory terms such as Natives, Bantus, and even Plurals which are also now regarded as derogatory. 


\section{The contemporary Xhosa lexicographical scenario}

It is quite surprising that after such a grand take-off, Xhosa lexicography did not attain great heights until the appearance of the first part (i.e. the third volume) of The Greater Dictionary of Xhosa in 1989. This volume ( $Q$ to $Z$ ) of the three volume dictionary was published by the University of Fort Hare at Alice. Its Editor-in-Chief was Professor H.W. Pahl, assisted by A.M. Pienaar and T.A. Ndungane, Senior Editors for Afrikaans and Xhosa respectively. Several minor dictionaries and wordlists appeared over the years but these were very inadequate as serious reference works.

Perhaps, as pointed out earlier, the best known of these smaller contemporary dictionaries is J. McLaren's A New Concise Xhosa-English Dictionary which was originally published by Longman as $A$ Concise Kafir-English Dictionary in 1915 and the orthography revised by Jolobe in 1963 . This dictionary was popular for some time but developments in the language soon made it inadequate for present-day use. A large number of current words and terms are totally missing in the dictionary. Although the dictionary had been updated, it still contained a large corpus of obsolete words, inkobongiyane for isayidi (siding), ukumbitha or ukumbina (to bury deep) and many others which have fallen into disuse.

Another popular dictionary, although it only gives word equivalents, is L.E. Jennings' The Concise Trilingual Dictionary which was published by Lovedale in 1961. It was updated in 1971. This was followed by H. Nabe, P.W. Dreyer and G.L. Kakana's Xhosa Dictionary: English/Xhosa/Afrikaans - Xhosa/English/Afrikaans in 1976.

One of the more ambitious and valuable contributions this era was certainly the English-Xhosa Dictionary by A. Fischer, E. Weiss, E. Mdala and S. Tshabe which was published by Oxford University Press in 1985. The dictionary became very useful for those who have to translate documents from English to Xhosa especially in the government services because it contains most of the common English words. The Xhosa side is very up-to-date as this contains words and terms in current use. The dictionary has filled the gap caused by the fact that McLaren's old English-Xhosa Dictionary is out of print.

The last two decades have seen a proliferation of small school dictionaries and wordlists. The first of these is K.B. Hartshorne, J.H.A. Swart and E. Posselt's Dictionary of Basic English-Xhosa Across the Curriculum which was published in 1984. We also have the Oxford Junior Primary Dictionary for Southern Africa which consists of an extensive list of Siswati, Xhosa and Zulu word equivalents. This joint effort by J.S. Goodwill and several co-authors appeared in 1991 simultaneously with one on Northern Sotho, Southern Sotho, Setswana and Afrikaans by Goodwill and other co-authors.

For the adult learner, the Reader's Digest has published in 1991 the South African Multi-Language Dictionary and Phrase Book, with an extensive vocabulary covering English, Afrikaans, Northern Sotho, Sesotho, Tswana, Xhosa and 
Zulu. The appearance of this dictionary coincided with conscious efforts on the part of South Africans to learn one another's languages as opposed to the apathy or even antipathy of the past.

\section{The Fort Hare Greater Dictionary of Xhosa}

Any study of Xhosa lexicography that does not embrace the great lexicographical work currently undertaken at Fort Hare cannot be complete. Since 1968 the Fort Hare University has embarked on a Xhosa-English-Afrikaans dictionary that promises to be a great contribution to both Xhosa language and lexicography. The dictionary was started by the late Professor H.W. Pahl, a German linguist of great talent whose fluency in Xhosa was impeccable, and after his retirement Professor P.T. Mtuze for a short time served as its Editor-in-Chief and when he left for Rhodes, Professor B.M. Mini took over as its Director and Editor-in-Chief. Volume 3 (from $Q$ to $Z$ ) has been published and will be briefly reviewed here while Volume 2 ( $\mathrm{K}$ to $\mathrm{P}$ ) and Volume 1 (A to $\mathrm{J}$ ) will follow soon. Several co-editors have been involved with the dictionary but suffice to say their valuable help has been a great source of inspiration to the Chief Editors. Although the Chief Editors' names are always mentioned, a dictionary of such magnitude is always a joint effort.

\section{Its policy and methodology}

Although there is no clearly formulated policy on research, word selection and the basis for inclusion and exclusion of words or terms, the introduction does touch on important policy and methodological issues. The lexicographers' objective view of the state of the arts in African languages today, especially Xhosa, is sufficiently broad to accommodate change and innovation in their attempts to record the language. Vide Pahl (1989: xxxii):

... history has proved that the Xhosa language is one of the tenaciously enduring elements of Xhosa culture, for it has maintained a firm footing on Southern African soil, growing like ar, evergreen, deep-rooted tree, and has manifested itself as a dynamic, vibrant, virile language adaptable to and developing in harmony with, the changing environment in that it sprouts new words and expressions to accommodate new concepts and cultural items, and to an even greater extent, absorbs and Xhosaizes foreign words and terms.

In the light of the foregoing, the lexicographers always remained acutely sensitive to words emanating from our cross-cultural context, ranging from contact with the Koisan and the European languages later on, e.g. ukulayita, (from 
lighting a lamp) which supplanted the more indigenous ukulumeka, udyakalashe (jackal) supplanting impungutye.

Pahl (1989: xxii) rightly points out that "because Xhosa has not as yet extended its roots deeply into the soil of scientific and technological fields, the lexicographers noted the extensive borrowing and Xhosaization currently taking place, and the coining of terms especially in the teaching profession when mother-tongue instruction was compulsory up to certain classes". He also points to blank areas where it is difficult to find Xhosa equivalents for English words like abstract, transparent, translucent, and opaque (Pahl 1989) but falls short of indicating how this problem has been overcome in the dictionary. Some reference to the problem will be made in my discussion later on.

The Greater Dictionary of Xhosa's method of lemmatization is simple and straight forward. It is much simpler than that of Kropf and Godfrey's (1915). Nouns and verbs are entered alphabetically according to the first letter of the stem. The prefix is demarcated through the use of a period as a marker indicating the start of the stem. The presentation of the full prefix serves a very useful purpose in so far as showing the complete lexical tone patterns as there are variations among the dialects and even among some regions.

One of the problems in Kropfs dictionary was with regard to Class 9 and 10 nominals. You never knew how these nominals were lemmatized because the dictionary's method was not quite satisfactory. In some cases, you had to struggle trying to look up words such as ingulube (the wild pig) as the entry could either be under $g$ or under $n$. Kropf tried to overcome this by writing under $n$ i-Ngulube $=$ in-Gulube, thus referring you to the entry under $g$. Pahl regards the $n$ as the initial letter of the stem and therefore lists the word ingulube under $n$ which to me is correct.

It is also of great significance, as far as policy is concerned, that The Greater Dictionary of Xhosa does not confine itself to Tshiwo Xhosa only. This is the language spoken in Ciskei and Gcalekaland and regarded as the standard because it was the dialect first reduced to writing by the missionaries. It also includes other dialectal and regional connotations as well as hlonipha (language of respect used by married women and the newly initiated boys). Many other variations in language usage are accommodated in the dictionary, some bordering on what could be stigmatized as colloquialism. In this way, the dictionary tries not to be prescriptive but to be as descriptive as possible, e.g. ayikho ntle instead of ayintle while the Mbo dialectal form ayintlanga is also included.

A much more bolder policy is with regard to allowing numerous borrowings from English and Afrikaans into the dictionary and thus legitimising their usage, e.g. imanioda, (from money order), noth (from not), ikharent akhawunti (current account) as well as the English counting system Xhosaized, ziyiten instead of zilishumi (they are ten). This is sometimes done so liberally that one tends to develop some scepticism about the wisdom of such wholesale borrowing. 


\section{A closer look at The Greater Dictionary of Xhosa}

The name of the dictionary will henceforth be abbreviated as the GDX.

I wish to agree with the lexicographers when they say on the dust cover:

The Greater Dictionary of Xhosa,

a project of the University of Fort Hare, is the first definitive trilingual dictionary in Southern Africa. For the first time, too, it amasses an unexpectedly large volume of data on the lexicon of the Xhosa language including material not only of semantic, but also of syntactic, morphological and phonological importance. The approach is wide, dealing with a comprehensive range of information of socio-linguistic importance set against the background of the Xhosa tradition and culture.

Perhaps it is exactly this voluminousness that made the first Editor-in-Chief to refer to the dictionary as "the unfinished dictionary" because it was so comprehensive that many other dictionaries could be extracted from the information contained therein. Despite its bulk and extensive coverage, the dictionary still remains a monumental work and a great contribution to knowledge.

Lexicologists and linguists have postulated several norms and criteria for lexicography. All these will not necessarily be applicable to the dictionary in question but are included here to complete the exercise. Some have a direct bearing on monolingual dictionaries only.

Leech (1974: 205) touches on several features normally associated with dictionary making. These will be paraphrased where possible.

1. A tendency to make dictionaries comprehensive even to the extent of defining easy words, e.g. wolf.

2. A tendency to use difficult or scientific terms as explanations, e.g. gregarious and carnivorous.

3. The use of feature symbols for layusers instead of paraphrase.

4. Explaining the headword with a word that is less widely used than the headword.

5. A tendency for dictionaries to go beyond the explanation of the mere sense of the term.

6. Mingling the function of a dictionary with that of an encyclopedia.

To this list, may be added a few other criteria by which dictionaries could be judged. One of these, from a practical point of view, is user-friendliness, a term much in vogue these days. Persuant to Louw's (1991: 118) list of eight semantic norms normally used to distinguish between lexical meaning and contextual meaning, the view will be taken that lexical meaning and contextual meaning are not the same thing. Most dictionaries fail to make a clear distinction regarding these phenomena. Prescriptiveness versus descriptiveness 
(Prinsloo 1991) will also be constantly monitored. These and other criteria will serve as the basis of this evaluation while the main focus will be on the dictionary's user-friendliness which largely subsumes most of these criteria.

One of the most commendable features of the GDX is its extensive list of the speech sounds and sound combinations of Xhosa. The IPA characters and the symbols used in South Africa for the click sounds will greatly facilitate pronunciation. The inclusion of the standard orthography should also serve a very useful purpose. Most people are not aware of the phoneme $z h$ for words like ithelevizhini whereas others still battle to make the distinction between ths and tsh in isithsaba (crown) and iintshaba (enemies), respectively.

A key to vowel pronunciation like the one below written by Mtintsilana (1990: 37) would have been of great benefit to those whose phonetics is not up to scratch:

The vowel sounds of Xhosa are simple sounds which McLaren (1963) compares to those of Latin or Italian. These sounds are not diphthongal like so many of the English sounds. The following comparison shows how Xhosa vowels compare with English sounds:

/ba/, as in English father, sofa;

Open /e/ (represented phonetically as $\varepsilon$ ) as in there; Close /e/ (phonetically e) as in the first part of brein;

/ $\mathrm{i}$ for which the tongue is higher than it is for kin;

Open /o/ (phonetically a) much like the vowel sound in road;

$/$ Close $/ 0 /$ (phonetically o) as in the first part of soul (without the rise to u);

$/ \mathrm{u} /$ as in rule.

The marking of the tone is to be appreciated especially if one bears in mind that Xhosa is a tone language and therefore some distinctions in the meaning of words are tone based, e.g. ithàngà (pumpkin), ithàngá (thigh) and ithângà (cattle-post). The importance of tone marking can be demonstrated by the (possibly apocryphal) story of the White farmer who wanted to deliver a speech at his servant's funeral. Amidst great expectations and admiration when this was known, he came forward and uttered the sentence "â Káfile ùlélè!" (Hail Kafir, you are asleep!) when he actually meant to utter the usual Christian condolence to the bereaved "akafilé úlélè" ( $\mathrm{He}$ is not dead but has merely taken a rest).

The various denotations or lexical meanings of each headword are listed, followed by some useful illustrations of the word's idiomatic usages, e.g. umga is said to have the following lexical meanings:

1. stiff porridge of maize meal; 
2. porridge of cooked pumpkin or melon mixed with maize meal or sorghum meal;

3. a tangled mass, e.g. of string, rope, etc.;

4. an involved matter that is difficult or impossible to solve or disentangle.

To my mind, 3 is a figurative use while 4 involves idiomatic usage. These should not have been listed in such a way that one could regard them as lexical meanings. They fall more under contextual meaning because some context is essential before one can grasp the meaning involved. The problem is aggravated when the main explanation under 4 suggests difficulty whereas one of the figurative uses listed thereunder suggests luck, e.g. ukuwelwa ngumqa esandleni (to have a stroke of luck). Of course this is more a notational issue than a factual inaccuracy.

The up-to-dateness of the dictionary can be attested to by the inclusion of current neologisms such as iqabane (comrade) which is a word that has come into the lexicon via current politics. Originally, this word meant an intimate friend and did not have any political connotations. The same applies to UQamata (the traditional Supreme Being). The dictionary clearly indicates the original meaning of this word and also shows that the word has acquired new meaning in that today it also refers to what they call "God of the Bible". The younger generation, especially, insist on this meaning as the missionaries were wont to use it in the Bible, hence they came up with Thixo. Many words which the early priests and missionaries shunned are now in use, e.g. ukuphehlelela (baptise) instead of ukubhaptiza. The missionaries associated the word with initiation into divinership. The tendency to revive traditional terminology for new situations can also be seen in Sesotho where mosuwe used to mean the guardian who looks after circumcised boys but today is used to refer to a teacher. What a pity the lexicographers did not give the current connotation of umtshana which means a friend whereas the original meaning of the word as pointed out in the dictionary (p. 379) was nephew or niece. Of course this could be regarded as a case of prescription by default. If a word is not contained in a standard dictionary, it is not regarded as acceptable or standard.

For the scientific inclined, there is every reason to recommend the dictionary. Although it does not purport to include technical terms and such scientific information, it does attempt to give scientific or Latin terms for some of the nominals. Umghaphu (milkweed) is known as Asclepias gibba and some of its sister plants are Gossypium spp. and Phormium Tenex in Transkei. The scientific term is only given after the ordinary term for the plant.

About the encyclopedic nature of the dictionary, it can only be said that this is by design. The extensive grammatical, historical, and cultural material given in the addenda is of great significance especially with regard to a people whose history, language and culture had been trampled underfoot for so long. 


\section{A word or two on the problem of translatability}

While every effort has been made to present the information as accurately as possible, the problem of untranslatability of certain words or concepts remains a real one as indicated earlier on.

Untranslatability is to the lexicographer what rejection is to the heart-transplant surgeon. To illustrate this, I wish to draw from my earlier article (Mtuze 1990). I shall make use of only one or two examples that are indicative of the abovementioned problem as found in the GDX and in general translation practice.

There are certain cultural issues that are very difficult to put across in the other language, worse still if that language is 'non-African' such as English and Afrikaans. That is why, in many cases, earlier language practitioners - especially in the legal profession - wisely decided to borrow terms directly from the vernacular, for example:

ukuthwala instead of 'abduction'

ukungena 'custom', instead of something like 'inheriting a deceased person's wife',

lobola instead of 'bride-price' or 'dowry'.

A close look at these examples will reveal slight differences in connotation in some cases, and rather serious differences in others, for example:

\section{Ukuthwala}

Xhosa:

English:

ukuthabatha ibhinga ulisa ekwendeni ngenkani.

Afrikaans: abduct a girl as a wife for a young man. 'n meisie skaak as vrou vir ' $n$ jongman.

The problem with regard to this phenomenon is firstly caused by the innocent-looking word 'abduct' in English which is a criminal action as it involves unlawfulness whereas ukuthwala in Xhosa is permissible under African law and custom. Secondly whereas in English, anyone can be abducted, whether it is a man or a woman, a child or an adult, the Xhosa word presupposes a woman of the marriageable age and the intention must be to marry her. These factors do not occur in 'abduct'.

The same kind of problems are found with regard to ukungena and 'lobola' as these words are culture bound. Any attempt to translate them out of their cultural context or from a Eurocentric perspective only, will certainly lead to distortion of meaning. For a fuller treatment of these problems, anyone still interested in pursuing this matter is referred to the article in question. The point has been made here that some of the cultural phenomena are at best paraphrasable but untranslatable. For some, only adequacy can be achieved, 
which means sufficient information is provided to enable someone outside the culture to have a clear idea of what is meant without necessarily trying to provide him or her with every detail of the source language message.

\section{Conclusion}

This historical and empirical study of lexicographical developments among the Africans culminated in an objective assessment of the greatest Xhosa dictionary so far, The Greater Dictionary of Xhosa which is compiled at Fort Hare, and of which Volume 3 has already been published. The dictionary promises to be a monument to both the Xhosa language, its editors, and to the university of Fort Hare itself. Having scrutinized the dictionary, and having used it occasionally to check up words, I express the same sentiments as those expressed by Professor A.L. Combrink (1992) in her review of Bosman, Van der Merwe and Hiemstra's Tweetalige Woordeboek/Bilingual Dictionary:

On the whole this Dictionary is the single most useful aid for the translator and other users. It rests on sound lexicographical principles and is, as stated above, most user-friendly.

What has also come out clearly in the article is that conscious efforts have been made to meet the demand for lexicographical works that can help bridge the linguistic gap among the various nations of the region. With the present developments in politics, it has become more and more essential for people to learn one another's languages. We also need to look back with great admiration on the efforts of the pioneering lexicographers and grammarians who devoted their lives to recording the indigenous languages to make them accessible to everyone interested in knowing them. Instead of forcing the indigenous peoples to learn the conquerors' languages only, like they did in America, the missionaries spearheaded a programme of mother-tongue literacy which has given us a heritage of vibrant, sonorant and outstanding indigenous languages which have withstood the force of other neighbouring languages and remained clearly identifiable as language entities despite unavoidable interinfluencing.

\section{References}

Appleyard, J.W. 1850. Kaffir and English Dictionary. King Williamstown: Wesleyan Missionary Press.

Ayliff, J. 1846. A Vocabulary of the Kafir Language. London: Wesleyan Mission House.

Barrow, J. 1797(?). Traoels into the Interior of Southern Africa. (This source also includes the "Vocabulary of Kaffer and Hottentot" in Vol. I: 173-174.) London: T. Cadell and W. Davis. 
Bennie, J. 1826. A Systematic Vocabulary of the Kaffrarian Language in Two Parts to which is prefixed an Introduction to Kaffrarian Grammar. Lovedale: Glasgow Mission Press.

Combrink, A.L. 1992. The User-friendly SA Dictionary. Academic Standard (Book Review Page) 1(3): 10. Cape Town: New National Media.

Davis, W.J. 1872. A Dictionary of the Kafir Language. London: Wesleyan Mission House.

Davis, W.J. 1877. English-Kafir Dictionary. London: Wesleyan Mission House.

Fischer, A., E. Weiss, E. Mdala and S. Tshabe. 1985. English-Xhosa Dictionary. Cape Town: Oxford University Press.

Goodwill, J.S., et al. 1991. Oxford Junior Primary Dictionary for Southern Africa. Siswati, Xhosa and Zulu Edition. Cape Town: Oxford University Press.

Hartshorne, K.B., J.H.A. Swart and E. Posselt. 1984. Dictionary of Basic English-Xhosa Across the Curriculum. Johannesburg. Educum.

Jennings, L.E. 1961. The Concise Trilingual Dictionary. Lovedale: Lovedale Press.

Kropf, A. and R. Godfrey. 1915. A Kafir-English Dictionary. Lovedale: Lovedale Press.

Leech, G. 1974. Semantics. Harmondsworth: Penguin Books.

Lichtenstein, H. von. 1805(?). Koossa Language. Bertuch und Vater's Allgemeines Archio filr Ethnographie und Linguistik 1: 250-331.

Louw, J.P. 1991. Semantiese norme in die leksikografie. South African Joumal of Linguistics 9(4): 115-118.

Mahlasela, B.E.N. 1973. A General Survey of Xhosa Literature from its Early Beginnings in the 1800 's to the Present. Working Paper 2. Grahamstown: African Languages, Rhodes University.

McLaren, J. 1915. A Concise Kafir-English Dictionary. London: Longmans.

McLaren, J. 1923. A Concise English-Kafir Dictionary. London: Longmans.

McLaren, J. 1963. A New Concise Xhosa-English Dictionary. Cape Town: Longman Penguin SA.

Mtintsilana, P.N. 1990. Lexicographic Work in Xhosa: Problems of Xhosa Lemmatization. Report LEXI-11. Pretoria: HSRC.

Mtuze, P.T. 1990. Problems of Equivalence and Adequacy in a Trilingual Context. South African Joumal of Linguistics 8(1): 30-32.

Nabe, H., P.W. Dreyer and G.L. Kakana. 1976. Xhosa Dictionary: English/Xhosa/Afrikans Xhosa/English/Afrikaans. King William's Town: Eduaum Publishers.

Pahl, H.W., A.M. Pienaar and T.A. Ndungane. 1989. The Greater Dictionary of Xhosa 3 (Q to Z). Alice: University of Fort Hare.

Pinchuk, I. 1977. Scientific and Technical Translation. London: Andre Deutsch.

Prinsloo, D.J. 1991. Prescriptiveness versus Descriptiveness: An Approach for Northem Sotho Lexicography. Unpublished paper delivered at the Sixth ALASA Conference, Port Elizabeth.

Reader's Digest. 1991. South African Multi-Language Dictionary and Phrase Book. Cape Town: The Reader's Digest Association.

Sparman, A. 1785. A Voyage to the Cape of Good Hope, towards the Antarctic Polar Circle, and Round the World: but Chiefly into the Country of the Hottentots and Caffres, from the Year 1772, to 1776. (This source contains the list "Specimen of the Language of Caffres" in Vol. II: 349-350.) London: G.G.J. and J. Robinson. 
Van der Kemp, J.T. 1803. Specimen of the Caffra Language. Transactions of the Missionary Society I: $442-458$.

Webster's Seaenth New Collegiate Dictionary. 1967. London: G. Bell and Sons. 